International Business Management 13 (9): 429-437, 2019

ISSN: $1993-5250$

(C) Medwell Journals, 2019

\title{
Attitudes, Abilities and Aspirations in the Worldwide Entrepreneurship Ecosystem
}

\author{
${ }^{1}$ Diego Araujo Reis, ${ }^{2}$ Fábio Rodrigues de Moura and ${ }^{1}$ Iracema Machado de Aragão \\ ${ }^{1}$ Program of Postgraduate in Department of Intellectual Property Science, \\ Federal University of Sergipe, São Cristóvão, Campus São Cristóvão, Brazil \\ ${ }^{2}$ Department of Economics, Federal University of Sergipe, São Cristóvão, \\ Brazil, Campus São Cristóvão, Cidade Univ
}

\begin{abstract}
This study aims to identify the effect of attitudes and abilities on aspirations in the entrepreneurship ecosystem. We use the sub-indices (attitudes, abilities and aspirations) of the Global Entrepreneurship Index (GEI) which measure the entrepreneurship ecosystem. The attitudes sub-index evaluate how competent individuals are to choose entrepreneurship rather than alternative occupations. The abilities sub-index measures the quality of new undertakings. The aspirations sub-index reflects the potential of start-ups to achieve internationalization, rapid growth and high productivity. Based on annual data from 2011-2018, we use a quantile regression model with fixed effects. We control for intellectual property and economic performance in addition to dummy variables that identify the particular impact on different regions. Our findings show a positive and heterogeneous effect of abilities on entrepreneur's aspirations and also a positive impact of attitudes on aspirations but only in higher quantiles. These findings contribute to the debate and are useful for formulating policies involving entrepreneurship in different countries.
\end{abstract}

Key words: Entrepreneurship ecosystem, attitudes, abilities, aspirations, global entrepreneurship index, quantile regression

\section{INTRODUCTION}

Schumpeter (1934) was the first to emphasize the importance of entrepreneurs in the innovation process. Entrepreneurs are responsible for the creative process using their attitudes, abilities, aspirations, among other features. Innovative entrepreneurs create new products, processes and services that drive the knowledge economy (Schumpeter, 1934; Hart, 2003; Mirzanti et al., 2015; Rami et al., 2017). It is recognised that entrepreneurship boosts productivity, innovation, job creation and economic growth (Hoffman 2007; Kastelle et al., 2018; Nogueira et al., 2019).

The scientific community has been increasingly investigating the entrepreneurship phenomenon, aiming to get a better understanding of the concept, content and behavior (Lundström and Stevenson, 2005; Ahmad and Seymour, 2008; Acs et al., 2009; Acs et al., 2014; Ahamat and Chong, 2015; Mirzanti et al., 2015; Szerb et al., 2016; Catalin et al., 2017; Szerb et al., 2019). A variety of metrics and indicators for measuring entrepreneurship have been developed that allow analyzing its phenomenon in different perspectives including different approaches to the ecosystem.

Szerb et al. (2016) argue that entrepreneurship is a multifaceted phenomenon and therefore it is impossible to measure in its totality. However, part of the literature tries to measure the entrepreneurship ecosystems such as the Global Entrepreneurship Index (GEI) that uses composite indicators. Created in 2014 with an earlier release version between 2011 and 2013 (Global Entrepreneurship and Development Index GEDI), the GEI comprises a combination of multiple dimensions of the business environment and classifies the data into three primary areas: attitudes, abilities and aspirations. Positive attitudes are understood as being necessary for competent individuals to choose entrepreneurship rather than alternative occupations. Ability reflects the quality of new undertakings and aspirations reflect the potential of enterprises to achieve internationalization, rapid growth and high productivity.

It is reasonable to suppose that, in the entrepreneurial environment, higher levels of attitudes and more abilities qualify individuals to have more aspirations. Attitudes and abilities provide the force for entrepreneurs to realize their innovation aspirations.

Our investigation identified a lack of studies that empirically assess the possible connections between attitudes, abilities and the entrepreneur's aspirations. This study aims to identify the effect of attitudes and abilities on aspirations in the entrepreneurship ecosystem.

We test the hypothesis that attitudes and abilities have a positive effect on aspirations in the entrepreneurial ecosystem, based on GEI (and GEDI) data, between 2011

Corresponding Author: Diego Araujo Reis, Program of Postgraduate in Department of Intellectual Property Science, Federal University of Sergipe, São Cristóvão, Campus São Cristóvão, Brazil 
and 2018, using a quantile regression model in a panel data setting. Our study analysis attitudes, abilities and the entrepreneur's aspirations on a different focus and the results are important for policymakers that seek to improve the entrepreneurship ecosystem.

Entrepreneurship ecosystem: Acs and Szerb (2009), Acs et al. (2009), Acs and Szerb (2012), Acs et al. (2013), Acs et al. (2014) and Szerb et al. (2018) define the entrepreneurship ecosystem as complex collaborative network of dynamically interacting systems and sub-systems within a set of dependencies and inter-dependencies that is continuously changing.

Acs et al. (2009), Acs and Szerb (2009), Acs and Szerb (2012), Autio and Thomas (2013), Acs et al. (2013), Acs et al. (2014) and Szerb et al. (2016) recognise the systemic nature of entrepreneurship at the national level and that individuals drive entrepreneurship. Acs et al. (2014) argue that in the entrepreneurship ecosystem, individuals incorporate business attitudes, abilities and aspirations in a dynamic interaction process.

Innovative entrepreneurs are the core of the system and they are characterised as having varying levels of business abilities and aspirations. They start a business in search of perceived opportunities which are validated in the process of trial and error (Acs et al., 2014). Entrepreneurship is regulated by a series of structural conditions (market structure, infrastructure, research and development system, financial sector, corporate sector, government, educational system). Acs et al. (2014) and the GEI report (2017) argue that a healthy entrepreneurship ecosystem will lead to an efficient allocation of resources and will increase the total factor productivity through innovation.

Following Schumpeter (1934), the GEI (2017) understands that the entrepreneur has the responsibility of coordinating the allocation of scarce resources and the activities needed to achieve growth. This innovative entrepreneur will guarantee that the invention will have some usefulness and will contribute to raising productivity and economic growth. Aidis and Estrin (2013) recognise the role of institutions in the entrepreneurship ecosystem. Institutions determine the rules of the game including intellectual property rights and market regulations. The importance of institutions lies in its influence on economic incentives and resource allocation.

The entrepreneurship ecosystem is concerned with the quality of the incentive mechanisms created by institutions and its impact on economic growth. According to Aidis and Estrin (2013), institutions create incentives to allocate entrepreneurial talent to activities with higher private returns. The GEI (2017) observes that entrepreneurship ecosystems may allocate resources to more productive use and generate innovative activities that drive this process. In addition, the literature on entrepreneurship recognises the importance of financing opportunities and resources which is not trivial, especially when discussing resource allocation from existing activities into new ones. There is always associated risk in this process and the lack of resources prevents a good ecosystem performance. Venture capital may be a solution to this problem but is relatively scarce in underdeveloped countries.

Global entrepreneurship index: The Global Entrepreneurship Index was introduced in 2014 by The Global Entrepreneurship Network (GEN), following an earlier version between 2011 and 2013. It is an annual index that measures the entrepreneurship ecosystems of several countries. In 2018, the index was calculated for 137 countries. Szerb (2017) observes that the GEI is based on a holistic view of different aspects of the entrepreneurship ecosystem.

According to Table 1, the index methodology consists of constructing sub-indices at several levels for each country. The data contains 14 sub-areas that generate three sub-indices: attitudes, abilities and aspirations. The global entrepreneurship index is an average of these three sub-indices. The GEI and its sub-indices range between 0 and 100 and the higher the score, the more developed will be the entrepreneurship ecosystem.

According to the GEI (2017), the business attitudes sub-index captures entrepreneurial attitudes and weights it with some important institutional variables. It involves the entrepreneurial opportunities the population perceives, weighted by economic freedom and property rights, the start-up abilities the population perceives, weighted by the quality of education, risk acceptance that is the fear of failure in entrepreneurship, combined with a measure of a country's risk, entrepreneurial support networks (ease of access), how the population view entrepreneurs in terms of status and career choice and how the corruption level affects this view.

The entrepreneurial abilities sub-index measures important entrepreneur characteristics that determine the potential of new start-ups to grow such as: motivation based on opportunity rather than based on necessity (weighted by the combined effect of taxation and the quality of government services), the potential of start-up activity (combined with the ability to absorb new technology), the educational level of entrepreneurs (weighted by the percentage of start-ups founded by individuals with academic degree or secondary education, by a measure of the entrepreneur's propensity to training their employees and by labour freedom), the level of product exclusivity or start-up market exclusivity, combined with the market power as well as the effectiveness of competitive regulations (GEI, 2017). 
Int. Business Manage., 13 (9): 429-437, 2019

Table 1: Composition of the Global Entrepreneurship Index (GEI)

\begin{tabular}{|c|c|c|}
\hline Sub-index & Pillars & Variables \\
\hline Global entrepreneurship index & & \\
\hline \multirow[t]{10}{*}{ Attitudes sub-index } & \multirow[t]{2}{*}{ Opportunity perception } & Opportunity Recognition \\
\hline & & Freedom (Economic Freedom*Property Rights) \\
\hline & \multirow[t]{2}{*}{ Start-up skills } & Skill Perception \\
\hline & & Education (Tertiary Education*Quality of Education) \\
\hline & \multirow[t]{2}{*}{ Risk acceptance } & Risk Perception \\
\hline & & Country Risk \\
\hline & \multirow[t]{2}{*}{ Networking } & Know Entrepreneurs \\
\hline & & Agglomeration (Urbanisation*Infrastructure) \\
\hline & \multirow[t]{2}{*}{ Cultural support } & Career Status \\
\hline & & Corruption \\
\hline \multirow[t]{8}{*}{ Abilities sub-index } & \multirow[t]{2}{*}{ Opportunity start-up } & Opportunity Motivation \\
\hline & & Governance (taxation*Good Governance) \\
\hline & \multirow[t]{2}{*}{ Technology absorption } & Technology Level \\
\hline & & Technology Absorption \\
\hline & \multirow[t]{2}{*}{ Human capital } & Educational Level \\
\hline & & Labour Market (Staff Training*Labour Freedom) \\
\hline & \multirow[t]{2}{*}{ Competition } & Competitors \\
\hline & & Competitiveness (Market Dominance*Regulation) \\
\hline \multirow[t]{10}{*}{ Aspiration sub-index } & \multirow[t]{2}{*}{ Product innovation } & New Product \\
\hline & & Tech Transfer \\
\hline & \multirow[t]{2}{*}{ Process innovation } & New Technology \\
\hline & & $\begin{array}{l}\text { Science (Gerd*(Average Quality of Scientific Institutions + Availability } \\
\text { of Scientists and Engineers)) }\end{array}$ \\
\hline & \multirow[t]{2}{*}{ High growth } & Gazelle \\
\hline & & Finance and strategy (Venture Capital*Business Sophistication) \\
\hline & \multirow[t]{2}{*}{ Internationalisation } & Export \\
\hline & & Economic complexity \\
\hline & \multirow[t]{2}{*}{ Risk capital } & Informal Investment \\
\hline & & Depth of capital market \\
\hline
\end{tabular}

GEI (2017)

Finally, the entrepreneurial aspirations sub-index captures the distinctive and qualitative aspects of the entrepreneurial activity: the tendency of companies to create new products, weighted by a country's ability to transfer technology, the use of new technologies for start-ups, combined with Gross Domestic Expenditure on Research and Development (GERD) and the potential of a country to perform applied research, percentage of high-growth companies that intend to hire at least ten employees and plan to grow by more than $50 \%$ in 5 years the availability of venture capital and the sophistication of business strategies, the degree of internationalisation, measured by the company's export potential and weighted by the country's economic complexity, the informal investment at earlier stages and a measure of the depth of capital markets (GEI, 2017).

In short, entrepreneurial attitudes characterises how a country thinks about entrepreneurship. Entrepreneurial abilities are entrepreneur's initiatives motivated by new opportunities. Entrepreneurial aspirations are the efforts of early-stage entrepreneurs to introduce innovations and expand their business, i.e., the potential of enterprises to achieve rapid growth and high productivity.

In the entrepreneurial ecosystem, countries need entrepreneurs that value business opportunities have the necessary abilities and wish to exploit the new opportunities. The GEI is formed by the results of attitudes, abilities and aspirations. However, the GEI methodology does not assess the possible causality between these sub-indices.

Empirical literature: Acs and Szerb (2009) were the precursors of the Global Entrepreneurship Index (GEINDEX). The authors hypothesised that the relationship between entrepreneurship and economic development is slightly S-shaped, not U or L-shaped and provided evidence that entrepreneurship across countries is positively related to economic development.

Bulut et al. (2013) analyzed six methodologies that measured entrepreneurship and innovation: IUS (Innovation Union Scoreboard), GEM (Global Entrepreneurship Monitor), GII (Global Innovation Index), ICI (Innovation Capacity Index), GEI (Global Entrepreneurship Index) and WCY (World Competitiveness Yearbook). The study also mapped and compared sample size, the quality of the indices, method of measurement and frequency, among other specifications.

Ghazinoory et al. (2014) took the GEI data to evaluate the influence of different social capital dimensions on the NIS (National Innovation System) in 34 countries. Using exploratory factor analysis and structural equation modelling, these authors detected a 
strong positive effect of institutional confidence and networking on entrepreneurship. Nataraajan and Angur (2014) analyzed the impact of the knowledge economy, using the Knowledge Entrepreneurship Index (KEI) and the business activity, using the Global Entrepreneurship Index (GEI), on the quality of life (QoL) in a country. The data were analysed using correlation and regression analysis and it was found that the KEI and GEI have a significant effect on the quality of life.

Inacio et al. (2016) examined the Brazilian entrepreneurship ecosystem using the GEI and the National System of Entrepreneurship (NSE) theory. The study indicates that the institutional interaction in Brazil has a low-to-middle quality andthe social context is the primary bottleneck in the national entrepreneurship ecosystem. The researcher also demonstrated that the Brazilian entrepreneurship ecosystem shows low internationalisation of its companies and reduced innovation in products and processes, among other problems.

Szerb et al. (2016) argue how the GEI methodology is projected to trace National Entrepreneurship Systems. The researcher used the Penalty for Bottleneck (PFB) methodology to compare the business performance of the European Union (EU) and the USA and the evidence shows that the former lags behind the latter. Szerb et al. (2016) report that a uniform policy does not work in the EU member states which requires the application of different combinations of policies to improve the GEI scores.

Jovanovic et al. (2017) compared the metrics of composite indices used in Technology Management (TM): The Global Competitiveness Index (GCI), the Global Innovation Index (GII) and the GEI. The researcher also analysed the correlations between the GCI and GII pillars and found that the indices perform Technology Management (TM) treatment. However, they observed a lack of composite indicators used exclusively for TM performance measured globally by official institutions.

Catalin et al. (2017) examined the evolution of the GEI in the top ten countries between 2015 and 2017. The authors found an absolute dominance of the USA and the growing presence of European countries. Szerb (2017) assessed the possibilities for developing Hungarian entrepreneurship with the help of the GEI. The author identified the following weaknesses in the Hungarian entrepreneurship ecosystem: opportunity recognition, product innovation, financing and competition.

Atiase et al. (2018) investigated the role of four critical resources on explaining the entrepreneurship quality and business support in Africa. The authors used the GEI data for 35 African countries, some important covariates obtained from the World Bank (credit access, electricity access and contract enforcement in Africa), the
Ibrahim Index of African Governance and other control variables (GDP, Foreign Direct Investment, population and education). The authors used OLS regressions and discovered that electricity access and governance policy were statistically significant and positively correlated with the GEI. Credit access was not significant to explain the response variables.

Szerb et al. (2019) studied the relevance of quantity and quality of entrepreneurship for regional performance through the moderating role of the entrepreneurial ecosystem. The researcher analyzed how the entrepreneurial ecosystem and different types of entrepreneurship impact local performance in 121 European regions for the period of 2012-2014. Szerb et al. (2018) used data of the Regional Entrepreneurship and Development Index (REDI) and discovered that quantity Kirznerian entrepreneurship negatively affects regional performance while this effect turns positive in the case of quality Schumpeterian entrepreneurship.

The empirical literature revealed somevaluable insights. However, not a single study investigated the relationship between attitudes and abilities on aspirations in the entrepreneurship ecosystem. We assume that attitudes and abilities provide the impulse for entrepreneurs to increasingly aspire for innovation. Therefore, we test the following hypothesis.

Hypothesis: Attitudes and abilities have a positive effect on aspirations in the entrepreneurial ecosystem.

\section{MATERIALS AND METHODS}

This is a quantitative study based on documentary research. Information on the sample design and empirical strategy is provided in the following sections.

Sample design: Our sample was constructed based on the availability of the GEI sub-indices (attitudes, abilities and aspirations). The sub-indices are available on the Global Entrepreneurship Network (GEN) annual reports, between 2011 and 2018. However, the current year GEI is always based on country data from the past two years. Thus, for estimation purposes, we decided to lag the GEI sub-indices by two years (2009-2016). Table 2 shows that the first year of the GEI covered only 71 countries and increases to 137 in 2016.

Given the changes and discontinuity in the GEI structure, we decided to conduct the investigation using all the available data (both time series and cross-country data). That results in an unbalanced panel. In addition to the GEI sub-indices, we control for some variables related to economic activity and intellectual property, obtained from the World Bank, according to Table 3.

Empirical model: Assuming high heterogeneity in the structural relationship and the presence of unobserved country characteristics, we estimate a quantile regression 
Int. Business Manage., 13 (9): 429-437, 2019

Table 2: Number of countries mapped by the GEI that presented the results of sub-indices

\begin{tabular}{|c|c|c|c|c|c|c|c|c|}
\hline Countries covered by the GEI & $2009^{1}$ & $2010^{1}$ & $2011^{1}$ & 2012 & 2013 & 2014 & 2015 & 2016 \\
\hline Total & 71 & 79 & 118 & 120 & 130 & 132 & 137 & 137 \\
\hline
\end{tabular}

The authors (2019). The GEI data for 2009-2011 correspond to the previous version (Global Entrepreneurship and Development Index) which varied between 0 and 1 . The data for 2009-2011 were multiplied by 100 to match the earlier version with the current one. For more information on the methodology and the imputation process, see the annual reports

Table 3: Variables code

\begin{tabular}{ll}
\hline Variable & Code \\
\hline Attitudes & ATT \\
Abilities & ABI \\
Aspirations & ASP \\
Gross domestic product per capita based on purchasing power parity-international dollars based on the 2011 ICP round & GDP \\
Number of scientific and technical journal articles per capita & ARTICLES \\
Number of patent applications non-residents per capita & PATNRES \\
Number of patent applications residents per capita & PATRES \\
Number of trademark applications non-residents and residents per capita & TRADNRES \\
Number of trademark applications residents and residents per capita & TRADRES \\
\hline
\end{tabular}

Authors (2019)

model with fixed effects as suggested by Bache et al. (2013). In addition, to controlling for unobserved time-invariant heterogeneity, the quantile regression may assess the effect of a particular covariate across different quantiles of the response variable which makes the inference more informative and robust.

Koenker and Bassett (1978) were pioneers in quantile regression. Koenker (2004) proposes an estimator for longitudinal data. According to the literature, there are still some limitations such as including a large number of fixed effects and their influence on the unconditional response of different quantiles. Powell (2014) also developed an estimator that addresses this problem and is unconditional of the fixed effects.

Bache et al. (2013) address the problem of assuming fixed effects in small panels (which generally occur if we attempt to balance a panel). The authors propose a solution using the Correlated-Random-Effects (CRE) estimator which controls for the possible (time-invariant) dependence between the fixed effects and a set of (or possibly all) covariates. Since, the fixed effects are not directly estimated, the distribution of the response variable is unconditional on the fixed effects. The CRE general model (Bache et al., 2013) assumes the general structure.

$$
\mathrm{y}_{\mathrm{it}}=\mathrm{x}_{\mathrm{it}} \beta(\tau)+\mathrm{s}_{\mathrm{i}} \pi+\varepsilon_{\mathrm{it}}
$$

We estimate the following CRE Model:

$$
\begin{aligned}
& \operatorname{ASP}_{\mathrm{it}}=\beta_{0}(\tau)+\beta_{1}(\tau) \operatorname{ATT}_{\mathrm{it}}+\beta_{2}(\tau) \mathrm{ABI}_{\mathrm{it}}+\beta_{3}(\tau) \mathrm{GDP}_{\mathrm{it}}+ \\
& \beta_{4}(\tau) \text { ARTICLES }_{\mathrm{it}}+\beta_{5}(\tau) \operatorname{PATNRES}_{\mathrm{it}}+\beta_{6}(\tau) \operatorname{PATRES}_{\mathrm{it}}+(2) \\
& \beta_{7}(\tau) \text { TRADNRES }_{\mathrm{it}}+\beta_{8}(\tau) \text { TRADRES }_{\mathrm{it}}+\mathrm{D}_{k}+\mathrm{s}_{\mathrm{i}} \pi+\varepsilon_{\mathrm{it}}
\end{aligned}
$$

Where, $i$ is the index for countries and is the index for years. The time-invariant unobserved effects are controlled by the covariate vector $s_{i}$, generated by
Table 4: Planet regions code

\begin{tabular}{ll}
\hline Regions & Code \\
\hline Europe & EUR \\
North America & NAC \\
Latin America and the Caribbean & LCN \\
Central and Southern Asia & CSA \\
Southeast Asia, East Asia, and Oceania & SEAO \\
Northern Africa and Western Asia & NAWA \\
Sub-Saharan Africa & SSF \\
\hline
\end{tabular}

Researcher (2019)

repeated measurements of the time-varying covariates (time-invariant covariates such as geographic region are not used to construct $\mathrm{s}_{\mathrm{i}}$ ). In general is constructed using the means (averages over time) of the time-varying covariates. This allows for unobserved characteristics to correlate with the covariates. In addition, the unobserved effects may affect both the scale and location of the response distribution. The $\mathrm{s}_{\mathrm{i}}$ vector enters linearly in the criterion function and the unobserved effects are allowed to vary with each quantile. The estimator proposed by Bache et al. (2013) allows for unbalanced panels is constructed using the annual data available for each country). Our model was estimated using log variables ( $\mathrm{s}_{\mathrm{i}}$ is coefficients are elasticities) and are $\mathrm{D}_{\mathrm{K}}$ dummies to capture the particular effect of different regions on aspirations. The regions follow the United Nations criteria, according to Table 4 is $\varepsilon_{\text {it }}$ the idiosyncratic error term.

\section{RESULTS AND DISCUSSION}

Descriptive statistics: Table 5 shows the descriptive statistics for the variables. It is noted that the mean, median values and the standard deviation of entrepreneurial attitudes, abilities and aspirations are relatively close.

GDP and the other control variables are more heterogeneous. Figure 1 shows the dispersion between as 
Int. Business Manage., 13 (9): 429-437, 2019

Table 5: Descriptive statistics for the variables (2011-2016)

\begin{tabular}{lllllll}
\hline Estatistic & Mean & Median & SD & Minimum & Maximum & Observations \\
\hline ATI & 35.66 & 33.00 & 17.56 & 4.00 & 86.00 & 924 \\
ABI & 36.17 & 32.08 & 18.14 & 5.00 & 97.00 & 924 \\
ASP & 33.37 & 28.85 & 19.52 & 2.00 & 89.50 & 924 \\
GDP & $19,099.61$ & $12,356.40$ & $19,930.02$ & 689.01 & $124,024.57$ & 1535 \\
ARTICLES & $13,106.08$ & 550.00 & $46,407.32$ & 1.10 & 440,229 & 1536 \\
PATNRES & $7,066.93$ & 244.50 & $29,098.35$ & 1.00 & 310,244 & 1036 \\
PATRES & $14,443.29$ & 257.00 & $76,035.18$ & 1.00 & $1,204,981$ & 997 \\
TRADNRES & $7,855.05$ & $4,068.00$ & $11,433.59$ & 167.00 & 115,850 & 1047 \\
TRADRES & $26,847.79$ & $3,530.00$ & $116,571.36$ & 2.00 & $1,997,058$ & 1047 \\
\hline
\end{tabular}

Researcher (2019)

Table 6: Descriptive statistics quantile median for the variables (2011 to 2016)

\begin{tabular}{llllllllll}
\hline Variables & $10 \%$ & $20 \%$ & $30 \%$ & $40 \%$ & $50 \%$ & $60 \%$ & $70 \%$ & $80 \%$ & $90 \%$ \\
\hline ATI & 14.16 & 19.76 & 24.90 & 29.00 & 33.00 & 37.70 & 43.40 & 49.78 & 61.34 \\
ABI & 16.21 & 20.92 & 24.30 & 27.82 & 32.08 & 36.00 & 42.00 & 51.18 & 65.07 \\
ASP & 2.00 & 12.00 & 15.00 & 19.19 & 24.10 & 28.85 & 34.08 & 42.86 & 53.00 \\
GDP & $1,873.81$ & $3,533.24$ & $6,104.23$ & $8,854.33$ & $12,400.89$ & $16,668.13$ & $23,320.25$ & $32,922.69$ & $44,085.76$ \\
ARTICLES & 24.08 & 67.06 & 154.65 & 298.24 & 588.95 & $1,265.30$ & $4,630.40$ & $10,708.12$ & $31,803.18$ \\
PATNRES & 7.20 & 21.00 & 50.20 & 132.80 & 235.00 & 380.20 & 864.20 & $3,397.40$ & $13,429.60$ \\
PATRES & 1.00 & 7.00 & 20.00 & 66.60 & 136.00 & 245.00 & 618.40 & $1,099.20$ & $2,020.80$ \\
TRADNRES & $1,100.20$ & $1,828.20$ & $2,283.80$ & $2,978.60$ & $3,772.50$ & $5,110.20$ & $7,480.90$ & $11,054.20$ & $18,895.30$ \\
TRADRES & 2.00 & 285.30 & 757.20 & $1,272.40$ & $2,182.60$ & $3,440.50$ & $6,727.00$ & $13,140.00$ & $21,486.60$ \\
\hline
\end{tabular}

Researcher (2019)
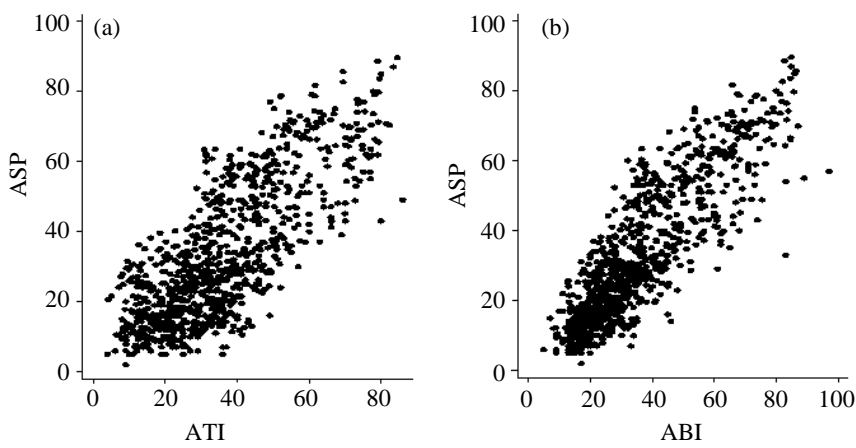

Fig. 1 (a, b): Dispersion of attitudes, abilities and aspirations in the period (2011-2016), Researcher (2019)

piration's responses and attitudes and abilities. We observe that attitudes and abilities are linearly associated with entrepreneurial aspirations.

The 137 countries of the sample have very distinct economic, social, political, cultural and territorial characteristics, among others. For a proper evaluation of the heterogeneous behaviour of the sample, we display the descriptive statistics by quantiles, according to Table 6 . The data was stratified into nine quantiles, allowing to form groups of countries with specific characteristics. Thus, the behavior of the distribution of observations is distinct in each quantile.

Results for quantile regression: Table 7 shows the estimated results for all variables. The effect of attitudes is positive and significant at the right tail of the response distribution are negative and significant for the 10 and $20 \%$ quantiles and are not significant between the 30 and $50 \%$ quantiles. The effect of abilities is positive and significant for all quantiles. These results validate the hypothesis of this study: attitudes and abilities affect aspiration results. Higher levels of entrepreneurial attitudes increase entrepreneurial aspirations, except for some countries in the lower quantiles. On the other hand, higher levels of entrepreneurial abilities enhance the potential of start-ups to achieve internationalization, rapid growth and high productivity through innovation. In general, this result demonstrates the importance of attitudes and abilities in determining the entrepreneurial aspirations indifferent countries. Higher levels of attitudes and the accumulation of abilities qualify individuals to have more aspirations. Attitudes and abilities provide the energy for entrepreneurs to pursue their aspirations for innovation.

Furthermore, the magnitude of the effect of attitudes and abilities tends to change as we move from the left to the right tail. Thus, it is reasonable to assume the hypothesis that countries with different levels of entrepreneurial aspirations respond differently to their attitudes and abilities. However, this cannot be clearly 
Int. Business Manage., 13 (9): 429-437, 2019

Table 7: Results for quantile regressions using the CRE estimator

\begin{tabular}{|c|c|c|c|c|c|c|c|c|c|}
\hline ASP & 0.1 & 0.2 & 0.3 & 0.4 & 0.5 & 0.6 & 0.7 & 0.8 & 0.9 \\
\hline$\overline{\text { ATT }}$ & $\begin{array}{l}-0.1370^{*} \\
(0.08)\end{array}$ & $\begin{array}{l}-0.2595 * * * \\
(0.10)\end{array}$ & $\begin{array}{l}0.157 \\
(0.15)\end{array}$ & $\begin{array}{l}0.1241 \\
(0.09)\end{array}$ & $\begin{array}{l}0.2053 \\
(0.13)\end{array}$ & $\begin{array}{l}0.5876^{* * *} \\
(0.16)\end{array}$ & $\begin{array}{l}0.4815^{* * *} \\
(0.10)\end{array}$ & $\begin{array}{l}0.5213 * * * \\
(0.08)\end{array}$ & $\begin{array}{l}0.3291 \text { *** } \\
(0.10)\end{array}$ \\
\hline $\mathrm{ABI}$ & $\begin{array}{l}1.1761 * * * \\
(0.17)\end{array}$ & $\begin{array}{l}1.2653 * * * \\
(0.18)\end{array}$ & $\begin{array}{l}1.0525 * * * \\
(0.11)\end{array}$ & $\begin{array}{l}0.9913 * * * \\
(0.10)\end{array}$ & $\begin{array}{l}0.7125 * * * \\
(0.09)\end{array}$ & $\begin{array}{l}0.6275 * * * \\
(0.09)\end{array}$ & $\begin{array}{l}0.5859 * * * \\
(0.13)\end{array}$ & $\begin{array}{l}0.3801 * * * \\
(0.10)\end{array}$ & $\begin{array}{l}0.2073 * * * \\
(0.06)\end{array}$ \\
\hline GDP & $\begin{array}{l}0.1717 \\
(0.33)\end{array}$ & $\begin{array}{l}1.2919 * * * \\
(0.31)\end{array}$ & $\begin{array}{l}0.7719 * * * \\
(0.23)\end{array}$ & $\begin{array}{l}0.2226 \\
(0.27)\end{array}$ & $\begin{array}{l}0.5288 \\
(0.59)\end{array}$ & $\begin{array}{l}1.4992 * * * \\
(0.31)\end{array}$ & $\begin{array}{l}0.9451 * * * \\
(0.25)\end{array}$ & $\begin{array}{l}1.3013^{* * *} \\
(0.19)\end{array}$ & $\begin{array}{l}1.4415^{* * *} \\
(0.20)\end{array}$ \\
\hline ARTICLES & $\begin{array}{l}1.0489 * * * \\
(0.40)\end{array}$ & $\begin{array}{l}1.0427^{* * * *} \\
(0.23)\end{array}$ & $\begin{array}{l}0.5765^{* * * *} \\
(0.09)\end{array}$ & $\begin{array}{l}0.4868 * * * \\
(0.08)\end{array}$ & $\begin{array}{l}0.4128^{* * * *} \\
(0.13)\end{array}$ & $\begin{array}{l}0.0978 \\
(0.07)\end{array}$ & $\begin{array}{l}0.0896^{*} \\
(0.05)\end{array}$ & $\begin{array}{l}-0.0819^{* *} \\
(0.03)\end{array}$ & $\begin{array}{l}-0.1053^{* *} \\
(0.04)\end{array}$ \\
\hline PATNRES & $\begin{array}{l}-0.1059 * * \\
(0.05)\end{array}$ & $\begin{array}{l}0.0036 \\
(0.04)\end{array}$ & $\begin{array}{l}0.0462 * * * \\
(0.01)\end{array}$ & $\begin{array}{l}0.0096 \\
(0.03)\end{array}$ & $\begin{array}{l}0.0297 \\
(0.03)\end{array}$ & $\begin{array}{l}-0.0028 \\
(0.03)\end{array}$ & $\begin{array}{l}0.0406 \\
(0.02)\end{array}$ & $\begin{array}{l}0.0968^{* * *} \\
(0.01)\end{array}$ & $\begin{array}{l}0.0164 \\
(0.03)\end{array}$ \\
\hline PATRES & $\begin{array}{l}0.1448 \\
(0.09)\end{array}$ & $\begin{array}{l}-0.0178 \\
(0.03)\end{array}$ & $\begin{array}{l}-0.0452 \\
(0.03)\end{array}$ & $\begin{array}{l}-0.1004 * * \\
(0.04)\end{array}$ & $\begin{array}{l}-0.0017 \\
(0.02)\end{array}$ & $\begin{array}{l}0.0559^{*} \\
(0.03)\end{array}$ & $\begin{array}{l}-0.0600 * * \\
(0.03)\end{array}$ & $\begin{array}{l}-0.0914 * * * \\
(0.02)\end{array}$ & $\begin{array}{l}-0.1141^{* * * *} \\
(0.03)\end{array}$ \\
\hline TRADNRES & $\begin{array}{l}-0.1749 \\
(0.15)\end{array}$ & $\begin{array}{l}-0.0345 \\
(0.07)\end{array}$ & $\begin{array}{l}-0.1063 * * \\
(0.05)\end{array}$ & $\begin{array}{l}-0.1376 \\
(0.09)\end{array}$ & $\begin{array}{l}-0.4115^{* * *} \\
(0.13)\end{array}$ & $\begin{array}{l}-0.6889 * * * \\
(0.14)\end{array}$ & $\begin{array}{l}-0.3162 * * * \\
(0.10)\end{array}$ & $\begin{array}{l}-0.2323^{* * *} \\
(0.07)\end{array}$ & $\begin{array}{l}0.008 \\
(0.09)\end{array}$ \\
\hline TRADRES & $\begin{array}{l}0.2889^{*} \\
(0.15)\end{array}$ & $\begin{array}{l}0.1909 \\
(0.20)\end{array}$ & $\begin{array}{l}-0.3046^{* * * *} \\
(0.06)\end{array}$ & $\begin{array}{l}-0.1946^{*} \\
(0.11)\end{array}$ & $\begin{array}{l}-0.0228 \\
(0.08)\end{array}$ & $\begin{array}{l}0.2558 * * * \\
(0.08)\end{array}$ & $\begin{array}{l}0.077 \\
(0.06)\end{array}$ & $\begin{array}{l}0.1398^{* * *} \\
(0.04)\end{array}$ & $\begin{array}{l}-0.0118 \\
(0.06)\end{array}$ \\
\hline EUR & $\begin{array}{l}0.5393 * * * \\
(0.11)\end{array}$ & $\begin{array}{l}0.1208^{*} \\
(0.07)\end{array}$ & $\begin{array}{l}0.1595^{* *} \\
(0.08)\end{array}$ & $\begin{array}{l}0.1394 * * * \\
(0.04)\end{array}$ & $\begin{array}{l}0.0956^{* *} \\
(0.05)\end{array}$ & $\begin{array}{l}0.0969^{*} \\
(0.06)\end{array}$ & $\begin{array}{l}-0.0395 \\
(0.04)\end{array}$ & $\begin{array}{l}-0.1307^{* * *} \\
(0.02)\end{array}$ & $\begin{array}{l}-0.0913^{* * *} \\
(0.02)\end{array}$ \\
\hline LCN & $\begin{array}{l}0.5426^{* *} \\
(0.23)\end{array}$ & $\begin{array}{l}-0.3606^{* *} \\
(0.16)\end{array}$ & $\begin{array}{l}-0.3659 * * * \\
(0.10)\end{array}$ & $\begin{array}{l}-0.084 \\
(0.07)\end{array}$ & $\begin{array}{l}-0.2352 * * * \\
(0.05)\end{array}$ & $\begin{array}{l}-0.1925^{* * *} \\
(0.03)\end{array}$ & $\begin{array}{l}-0.1228 * * * \\
(0.04)\end{array}$ & $\begin{array}{l}-0.2259^{* * *} \\
(0.03)\end{array}$ & $\begin{array}{l}-0.3294 * * * \\
(0.06)\end{array}$ \\
\hline NAC & $\begin{array}{l}0.4299 * * * \\
(0.13)\end{array}$ & $\begin{array}{l}-0.2263 * \\
(0.12)\end{array}$ & $\begin{array}{l}-0.2298 * * \\
(0.09)\end{array}$ & $\begin{array}{l}-0.1211 * * * \\
(0.04)\end{array}$ & $\begin{array}{l}-0.1839 * * * \\
(0.06)\end{array}$ & $\begin{array}{l}-0.1587 * * \\
(0.08)\end{array}$ & $\begin{array}{l}0.1004 * \\
(0.06)\end{array}$ & $\begin{array}{l}-0.0513 \\
(0.04)\end{array}$ & $\begin{array}{l}0.2522 \\
(0.16)\end{array}$ \\
\hline NAWA & $\begin{array}{l}1.0398 * * * \\
(0.15)\end{array}$ & $\begin{array}{l}0.4012 * * * \\
(0.12)\end{array}$ & $\begin{array}{l}0.3261 * * * \\
(0.11)\end{array}$ & $\begin{array}{l}0.3964 * * * \\
(0.06)\end{array}$ & $\begin{array}{l}0.3673 * * * \\
(0.07)\end{array}$ & $\begin{array}{l}0.1636^{* *} \\
(0.07)\end{array}$ & $\begin{array}{l}0.0356 \\
(0.06)\end{array}$ & $\begin{array}{l}-0.0385 \\
(0.04)\end{array}$ & $\begin{array}{l}-0.1323 * * * \\
(0.03)\end{array}$ \\
\hline SEAO & $\begin{array}{l}0.7191 * * * \\
(0.14)\end{array}$ & $\begin{array}{l}-0.0354 \\
(0.08)\end{array}$ & $\begin{array}{l}0.0847 \\
(0.07)\end{array}$ & $\begin{array}{l}0.1420 * * * \\
(0.05)\end{array}$ & $\begin{array}{l}0.0044 \\
(0.07)\end{array}$ & $\begin{array}{l}-0.0627 * * * \\
(0.02)\end{array}$ & $\begin{array}{l}-0.0168 \\
(0.03)\end{array}$ & $\begin{array}{l}-0.1138^{* *} \\
(0.05)\end{array}$ & $\begin{array}{l}-0.2717 * * * \\
(0.09)\end{array}$ \\
\hline SSF & $\begin{array}{l}0.3886^{*} \\
(0.21)\end{array}$ & $\begin{array}{l}-0.0751 \\
(0.06) \\
\end{array}$ & $\begin{array}{l}0.0024 \\
(0.11) \\
\end{array}$ & $\begin{array}{l}0.1729 * * * \\
(0.06)\end{array}$ & $\begin{array}{l}0.0983^{* *} \\
(0.04)\end{array}$ & $\begin{array}{l}0.2093^{* * *} \\
(0.05)\end{array}$ & $\begin{array}{l}-0.0345 \\
(0.07) \\
\end{array}$ & $\begin{array}{l}-0.0463 * \\
(0.03)\end{array}$ & $\begin{array}{l}-0.1400^{* * *} \\
(0.03)\end{array}$ \\
\hline
\end{tabular}

Researcher (2019). Asterisks denote the significance level: * $10 \% ; * * 5 \% ; * * 1 \%$. Bootstrapped standard errors are in parentheses

inferred for attitudes, since, there is an unexpected break between the 30 and $50 \%$ quantile. The control variables captured some significant effects on aspirations. It is important to highlight the significant and positive effect of GDP per capita, except for the 10, 40 and $50 \%$ quantiles. GDP per capita has a high elasticity at the right tail of the as pirations distribution. If we assume that GDP per capita is a proxy for economic development and that the aspirations sub-index is a proxy for entrepreneurship, the results confirm the hypothesis of Acs and Szerb (2009) regarding the relationship between entrepreneurship and economic development.

Although, the positive result for patent applications filed by residents is expected (since, resident applications may materialise into innovative products and processes that will be exploited by domestic individuals), we have a significant and negative effect for domestic applications at the 40, 70, 80 and $90 \%$ quantiles. One possible hypothesis to be tested is that in countries with higher aspirations, competition for patent applications is so intense that it may reduce aspirations by discouraging incumbent inventors. The competitive environment for patents is good but perhaps not in excess. Similar reasoning may be used for the number of scientific and technical journal articles which also exhibits an interesting negative effect in the right tail. Increasing scientific competition (proxied by scientific production) may reduce aspirations in countries that already have higher aspirations results (and thus that have been experiencing a more intense scientific competition). Patent applications filed by non-residents may also be reducing domestic aspirations because they are potential innovations that will be monopolised by foreign agents. This expectation may be causing a significant negative effect on the lower $10 \%$ quantile. However, this effect tends to decrease as aspirations rise. Countries with higher aspirations may have a higher probability to protect themselves more efficiently against the impact of nonresident patents and they may even absorb these prospective patents in favour of domestic entrepreneurship which would alter the negative effect into a positive or insignificant one as observed at the $80 \%$ quantile. Furthermore, countries with low aspirations may be correlated with "inefficient" domestic patent offices that have a large Backlog of pending patents in comparison to patent offices of countries with higher aspirations (USA, Canada, Europe, etc.).

Concerning the regional dummies (relative to CSA base level Central and Southern Asia), we find a significant and positive effect of the European continent on aspirations only at lower quantiles. The effect eventually declines and becomes negative between the 70 and $90 \%$ quantiles, reflecting the decrease in entrepreneurship as pirations in countries that already have better results for this sub-index. This requires the adoption of new and specific policies to reverse the declining trend in the entrepreneurship aspiration results 
in Europe as reported by Szerb et al. (2016). The other regions also have an overall negative effecton entrepreneurship aspirations, except at lower quantiles.

\section{CONCLUSION}

Our study aimed to identify the effect of attitudes and abilities on aspirations in the entrepreneurship ecosystem, measured by the Global Entrepreneurship Index. We observe the response at each quantile and control for fixed effects. The results indicate that attitudes and abilities have a positive but heterogeneous effect across the quantiles of the response distribution. We found, for example that entrepreneurship abilities contribute more to aspirations at lower quantiles, in comparison to the smaller effect at higher quantiles.

This study contributes to the discussion by presenting evidence that entrepreneurial activities and the quality of new enterprises directly impact the potential of rapid growth and high productivity in start-ups. The results require the attention of public and private authorities and Economic development agencies since aspirations may be maximised by improving attitudes and abilities in the entrepreneurship ecosystem.

Despite the advantages of using the GEI sub-indices in terms of country coverage there are some notable limitations associated with the fact that the sub-indices may not be a reliable portrayal of the entrepreneurial phenomenon investigated as entrepreneurial attitudes, abilities and aspirations are multifaceted phenomena. Despite the constant evolution of the index, countrie's characteristics are complex and difficult to capture. Nevertheless, the sub-indices are relevant proxies that produce strategic information for decision making regarding the management of the entrepreneurial ecosystem. We understand, though that more specific investigations are needed to analyse some possible controversial results.

\section{ACKNOWLEDGMENTS}

This study was financed in part by the Coordenação de Aperfeiçoamento de Pessoal de Nível Superior-Brasil (CAPES)-Finance Code 001. We are grateful for the support given by the State Agency to support Research and Technological Innovation of Sergipe (FAPITEC/SE/BRAZIL), Program of Postgraduate in Intellectual Property Science (PPGPI/UFS) and Program of Postgraduate in Economic (NUPEC/UFS).

\section{REFERENCES}

Acs, Z.J. and L. Szerb, 2009. The global entrepreneurship index (GEINDEX). Found. Trends Entrepreneurship, 5: 341-435.
Acs, Z.J. and L. Szerb, 2012. Global Entrepreneurship Index. Edward Edward Elgar Publishing Ltd., Cheltenham, England, Pages: 400.

Acs, Z.J., E. Autio and L. Szerb, 2014. National systems of entrepreneurship: Measurement issues and policy implications. Res. Policy, 43: 476-494.

Acs, Z.J., L. Szerb and E. Autio, 2013. Global Entrepreneurship and Development Index. Edward Edward Elgar Publishing Ltd., Cheltenham, England, ISBN: 9781849808446 , Pages: 352.

Acs, Z.J., P. Braunerhjelm, D.B. Audretsch and B. Carlsson, 2009. The knowledge spillover theory of entrepreneurship. Small Bus. Econ., 32: 15-30.

Ahamat, A. and S.C. Chong, 2015. Multi-methodological approaches in qualitative entrepreneurship research. Int. Bus. Manage., 9: 601-612.

Ahmad, N. and R.G. Seymour, 2008. Defining entrepreneurial activity: Definitions supporting frameworks for data collection. OECD Statistics Working Papers 2008/1, OECD, Paris, France. https://www.oecd-ilibrary.org/economics/definingentrepreneurial-activity_243164686763

Aidis, R. and S. Estrin, 2013. Institutions, Incentives and Entrepreneurship. In: The Global Entrepreneurship and Development Index, Acs, Z., L. Szerb and E. Autio (Eds.). Edward Elgar Publishing Ltd., Cheltenham, England, ISBN:9781782540427, pp: 18-26.

Atiase, V.Y., S. Mahmood, Y. Wang and D. Botchie, 2018. Developing entrepreneurship in Africa: Investigating critical resource challenges. J. Small Bus. Enterp. Dev., 25: 644-666.

Autio, E. and L.D.W. Thomas, 2013. Innovation Ecosystems: Implications for Innovation Man-Agement. In: The Oxford Handbook of Innovation Management, Dodgson, M., D. Gann and N. Phillips (Eds.), Oxford University Press, Oxford, UK., ISBN: 9780199694945, pp: 204-228.

Bache, S.H.M., C.M. Dahl and J.T. Kristensen, 2013. Headlights on tobacco road to low birthweight outcomes: Evidence from a battery of quantile regression estimators and a heterogeneous panel. Empirical Econ., 44: 1593-1633.

Bulut, C., E.E. Mutlu and M. Nazli, 2013. Innovation and entrepreneurship assessment initiatives: A critical view. Proceedings for the 8th Europen Conference on Innovation and Entrepreneurship (ECIE'13), September 19-20, 2013, Hogeschool Univ Brussel, Brussels, Belgium, pp: 126-135.

Catalin, G., T. Sorin-George and P. Razvan, 2017. Entrepreneurship in the World: The analysis of the global entrepreneurship index in the period 2015-2017. Ovidius Univ. Ann. Econ. Sci. Ser., 17: 14-18. 
Ghazinoory, S., A. Bitaab and A. Lohrasbi, 2014. Social capital and national innovation system: A cross-country analysis. Cross Cult. Manage., 21: 453-475.

Hart, D.M., 2003. The Emergence of Entrepreneurship Policy: Governance, Start-Ups and Growth in the US Knowledge Economy. Cambridge University Press, Cambridge, England, ISBN-13: 978-0-511-05628-4, Pages: 312 .

Inacio Jr. E., E. Autio, C. Morini, F.A.P. Gimenez and E.A. Dionisio, 2016. [Analysis of the Brazilian entrepreneurial ecosystem (In Portuguese)]. Dev. Question, 14: 5-36.

Jovanovic, M., J. Rakicevic, M.L. Jaksic, J. Petkovic and S. Marinkovic, 2017. Composite Indices in Technology Management: A Critical Approach. In: Emerging Trends in the Development and Application of Composite Indicators, Jeremic, V., Z. Radojicic and M. Dobrota (Eds.). IGI Global, Hershey, Pennsylvania, USA., ISBN: 9781522507154, pp: 38-71.

Kastelle, T., S. King, M.L. Verreynne and P. Kambouris, 2018. Experiences using a science-based Lean Launch Pad program and its impact on national innovation system evolution. Int. J. Entrepreneurship Small Bus., 35: 356-370.

Koenker, R. and G. Bassett Jr., 1978. Regression quantiles. Econometrica, 46: 33-50.

Koenker, R., 2004. Quantile regression for longitudinal data. J. Multivariate Anal., 91: 74-89.

Lundstrom, A. and L. Stevenson, 2005. Entrepreneurship Policy: Theory and Practice. Vol. 9, Springer, Berlin, Germany, ISBN: 9780387241401, Pages: 310.
Mirzanti, I.R., T.M. Simatupang and DwiLarso, 2015. A conceptual framework of entrepreneurship policy. Int. Bus. Manage., 9: 397-404.

Nataraajan, R. and G.M Angur, 2014. Innovative ability and entrepreneurial activity: Two factors to enhance quality of life. J. Bus. Ind. Marketing, 29: 469-475.

Nogueira, M.A., S. Fernandez-Lopez, M.J.R. Gulias, M. Vivel-Bua and D. Rodeiro-Pazos, 2019. The hidden effect of innovation on the growth of Spanish firms. Int. J. Entrepreneurship Small Bus., 37: 167-189.

Powell, D., 2014. Did the economic stimulus payments of 2008 reduce labor supply? Evidence from quantile panel data estimation. RAND Working Paper Series WR-710-3, RAND Corporation, Santa Monica, California, USA. https://www. rand.org/pubs/ working papers/WR710-3.html

Rami, H., D.V. Pasquale and P. Giuseppina, 2017. Performance entrepreneurship success: The roles of IT competencies on the corporate entrepreneurship orientation. Agric. J., 12: 15-22.

Schumpeter, J.A., 1934. The Theory of Economic Development: An Inquiry into Profits, Capital, Credit, Interest and the Business Cycle. Harvard University Press, Cambridge, MA.

Szerb, L., E. Komlosi, and B. Pager, 2016. Measuring entrepreneurship and optimizing entrepreneurship policy efforts in the European union. CESIFO. DICE. Rep., 14: 8-23.

Szerb, L., E. Lafuente, K. Horvath and B. Pager, 2019. The relevance of quantity and quality entrepreneurship for regional performance: The moderating role of the entrepreneurial ecosystem. Reg. Stud., 53: 1308-1320. 